\title{
Afghanistan: Military Occupation and Ethnocracy
}

\author{
James Goodman \\ Wahid Razi \\ University of Technology Sydney
}

\begin{abstract}
The 2001 invasion and subsequent occupation consolidated ethnicity as a political force in Afghanistan. Interethnic elite bargaining instituted an ethnocratic oligarchy, grounded in the occupation. Against this, everyday politics in Afghanistan has centred on social clientelism, founded on kinship networks rather than ethnicity. At the same time, formal political structures, expressed in the 2004 Constitution, are grounded in Islam and nationalist statehood rather than ethnicity. In recent years sharp disjunctures have emerged between ethnic elites and would-be constituents, creating some electoral fluidity and ethnic de-alignment. The paper addresses the relationship between occupation and ethnocracy in Afghanistan. It takes an historical perspective on the present, debating contending foundations for political solidarity and identification in the country.
\end{abstract}

Afghanistan is an illustrative case of all the three aspects of ethnocracy identified in the opening article to this Special Issue of Cosmopolitan Civil Societies Journal. First, the country is an artefact of imperial rivalry, initially as a buffer between British and Russian spheres of influence, and latterly as a stake in the Cold War US-Soviet rivalry. It became a US protectorate in 2001, and since 2014 has become autonomous, but remains a site of political intervention for regional powers. Second, it is currently an ostensibly post-conflict society, where the political process centres on overcoming insurgency and reconciling former rivals. Under the 2004 Constitution inter-ethnic conflict is subsumed in an effort at establishing multi-ethnic political solidarity through religion and nationalism. In practice though, Afghanistan's post-conflict politics has strong power-sharing aspects, centring on informal structures of ethno-military parity. Third, the politics of Afghanistan is grounded in forms of religious solidarity. All law is to be consistent with Islam, defined as a civic responsibility, with provision for different sects and for non-Islamic faiths.

The 2001 invasion, occupation, and subsequent anti-Taliban war have created a strong pressure to ethnocratic rule in Afghanistan. The logic of alliance-building and counter-

James Goodman, Faculty of Arts and Social Sciences, University of Technology Sydney; Wahid Razi, Faculty of Arts and Social Sciences, University of Technology Sydney. Corresponding author:

James.Goodman@uts.edu.au

ISSN: 1837-5391; https://epress.lib.uts.edu.au/journals/index.php/mcs

CCS Journal is published under the auspices of UTSePress, Sydney, Australia

(c) 2016 James Goodman, Wahid Razi. This is an Open Access article distributed under the terms of the

Creative Commons Attribution 4.0 Unported (CC BY 4.0) License

(https://creativecommons.org/licenses/by/4.0/), allowing third parties to copy and redistribute the material

in any medium or format and to remix, transform, and build upon the material for any purpose, even

commercially, provided the original work is properly cited and states its license.

Citation: Cosmopolitan Civil Societies Journal 2016, 8(3): http://dx.doi.org/10.5130/ccs.v8i3.5313 . 
insurgency after the 2001 invasion forced a heavy reliance on ethnically-defined militia groups. Yet, ethnocracy, defined as rule by the dominant ethnic group, albeit in alliance with subordinates, does not align well with Afghan political traditions. The identity of the Afghan state has historically centred on an interaction between regional or tribal solidarity, nationalism and Islam, rather than ethnicity per se. This article discusses the interaction between these forms of solidarity in Afghan history. It offers a brief history of ethno-national politics in the country, and discusses other forms of socio-political solidarity centred on clientelism and kinship networks. It outlines the ethnicisation of elite politics during the occupation, as the military alliance introduced an informal model of inter-ethnic powersharing into the workings of the Afghan state. In its final sections, the article assesses postoccupation political dynamics, beyond ethnicisation. It argues that pressure for inter-ethnic bargaining and for non-ethnic political contention appears to be strengthening in the context of a would-be pluralist state, as defined by the 2004 Afghan Constitution, and with the formal end of the US occupation. The article ends by assessing possibilities for ethno-political dealignment, for enabling political contention within a broadly nationalist and Islamic political field.

\section{Afghanistan and Empire}

Whilst never colonised, Afghanistan is an artefact of imperial rivalry. This is a critical factor in understanding its prospects. In the first instance, imperial power defined its territory. With the British failure to incorporate Afghanistan by invasion, the Eastern border of Afghanistan defined the limit of the British Empire in the nineteenth century. British efforts focused on delimiting the state through territorial acquisition. The eventual loss of eastern territory from Afghanistan to British India was defined in a one-page document in 1893 that established the 'Durand line' (Biswas 2013). Nineteenth century British-Russian rivalry was mirrored in the 1970s and 80s with the Pakistan-US alliance against the Soviet backed Afghan government. A Soviet military guarantee for the Afghan government in 1978 enabled the US to lure the Soviets to 'into the Afghan trap', to 'give the USSR its Vietnam war' (as Brzezinski, President Carter National Security Advisor put it; see Gibbs 2000). The effect of this was to create a decade-long civil war, in which the US armed warlords and Islamists (which later rebounded on the US with the formation of Al Qaeda). The assumption that foreign policy manipulations could only have consequences for the people living in those contexts was rudely shattered. The ensuing War on Terror very clearly demonstrated the extent to which 
the US and its allies were threatened by Al Qaeda insurgency (Goodman 2013). The UNsanctioned goal of rooting-out governments hosting $\mathrm{Al}$ Qaeda or groups deemed to be its associates was interpreted by the US as a green light to invade Taliban-held Afghanistan, and led to a more-than decade-long US occupation of the country (Williamson 2001). This brought the US and its allies into new state-building roles in Afghanistan, and the country has remained highly internationalised.

Again the future of Afghanistan sits at the centre of global empire - its future circumscribed by external forces. Not least among these is Pakistan, which was rehabilitated as a US partner in the war on the Taliban; concerns about military dictatorship and nuclear proliferation were set aside, and even the ongoing collaboration between elements of the Pakistani state and the Taliban was overlooked. In the process, a neighbouring country that has a strong interest in a weakened Afghan state has gained an important role in influencing the future of the country (Fair and Gregory 2013; Maley 2016). Pakistan, in fact, may exercise a veto power on state stability in Afghanistan.

Since 2005 these issues have been brought into sharp focus with the growing power of the Taliban, which has repositioned itself as a national liberation movement at war with the occupying forces, and their appointees (Kamel 2015). Reflecting this, the Afghan government opened negotiations with the Taliban for the transition to US withdrawal in 2014. A key element of this was recognition of de facto Taliban control over large segments of the country. The Taliban continues to strengthen its hand by alternating between political violence and negotiations, and this has persisted since the 2014 US withdrawal, partly driven by external interests (Maley 2016).

\section{A Brief Ethno-political History}

As a crossroad between different civilisations connecting East, South, West and Central Asia, the Afghan region has been a melting pot of many ethnic groups who came to the country as invaders or settlers during the pre-modern era. These groups included Aryans, Persians, Arabs, Turkish-speaking people from central Asia, people from Mongolia, the Xinjiang region of western China and ancient Macedonia. According to archaeological discoveries in the North and South of the country, in about 1500 B.C., the Aryans invaded the land which is known today as Afghanistan. In the mid-500s B.C., Persians invaded northern Afghanistan, a 
region then called Bactria. The Persians ruled Bactria until about 330 B.C., when the Greeks and Macedonians led by Alexander the Great conquered the region and much of the rest of Afghanistan. In about 246 B.C, the Bactrians formed a kingdom that lasted about 150 years, until the Kushans of central Asia seized the whole region (Holt 2012). Sasanians from Persia invaded Afghanistan in the 200 A.D., and White Huns from central Asia defeated the Kushans and Sasanians in the A.D. 400s.

The region became part of the Arab Muslim world in the late 600s, with the Muslim dynasties of Tahirid, Samanid, and Saffarid to the 900s. Turkic-speaking peoples from eastern Persia and central Asia ruled Afghanistan from about 900 to 1200, and Afghanistan was conquered by Mongols, led by Genghis Khan in the 1200s and by Timur, also called Tamerlane, in the 1300s. Safavids from Persia and Mughals from India struggled for control of Afghanistan from the mid-1500s to the early 1700s. By the eighteenth century the country had become a site of geopolitical tension between Persia and India, shaping migration flows, settlement patterns and affiliations.

Modern Afghanistan emerged under the Persian Empire in the mid eighteenth century, with Kabul as its capital from 1775. Internal conflict between the ruling tribal elites culminated in the rise of Dost Muhammad Khan, a tribal leader, who gained control as Amir (prince) in 1826. Dost Muhammad's descendants then ruled the country for the next 150 years (Axworthy 2009; Barfield 2010). During the nineteenth century Afghanistan became a competing ground for geopolitical influence between the British and Russian Empires (Fremont-Barnes 2014). Russia invaded large parts of Central Asia, including the northern parts of Afghanistan, seeking access to the Indian Ocean (Tripodi 2010). Trying to insulate colonial India, British troops invaded Afghanistan in 1839, and were defeated, withdrawing in 1842. With Russian advances into Central Asia, the Afghan Amir signed a friendship treaty with the Russians, precipitating a second British invasion in 1878. Afghanistan became a protectorate of the British empire in 1880 under a treaty assigning control of the country's external relations to the British, and later, in 1893 the Amir recognised the 'Durand Line' which consigned half of the country's territory, and half of its Pashtun population, to British India, and rendered Afghanistan landlocked (Balaachandar 2010).

In the early twentieth century Afghanistan embarked on its own national development program. In 1919 the Amir precipitated the third Anglo-Afghan war, which ended 
Afghanistan's protectorate status, allowing the country to become fully independent. The constitution was drawn up in 1923, based on the French model, and the Amir (now King Amanullah Khan), sought to Westernise the country, including the adoption of a European dress code. The Islamic authorities opposed the new dispensation, and in 1929 overthrew the King with the help of the army (and supported by the British) (Hiro 1995). Within the year a new King was installed, Nadir Shah, and the country was renamed the 'Islamic state of Afghanistan’. The King was assassinated in 1933 and his son, Zahir Shah, ruled until 1973.

In this forty years of political stability, 1933-73, Afghanistan experienced some degree of modernisation, although the country remained one of the world's least developed. The King introduced a constitutional monarchy under the 1964 constitution with free elections, allowing the formation of elected governments under the monarchy. During World War II Afghanistan was neutral, and in the Cold War it was closely aligned with the Soviet Union. At the same time the United States developed close military ties with Pakistan.

In 1973 a former Prime Minister, Daoud Khan, staged a successful coup against Zahir Shah, installing a republican administration while the King was in Italy (remarkably, the King was to return to the country to legitimise the transition of power after the US invasion in 2002, and died in 2007). Daoud Khan was ousted in 1978 in a military coup led by the MarxistLeninist ‘People’s Democratic Party of Afghanistan’ (PDPA) (Rubin 1995; Dimitrakis 2013). Once in power, divisions in the PDPA started to emerge, mainly between the urban elite and more radicalised rural cadres with strong links into the military. Fearing the collapse of the regime, the Soviet Union signed a treaty of friendship with the government in 1978, guaranteeing military assistance in the event of a threat to the country's territorial integrity (Krivosheev 1997). The regime became further destabilised with the forceful transfer of power from one faction to another, and was increasingly threatened by hostile forces internally and on the Pakistan border (Khan 2011). The Soviet state bolstered the regime, sending ministerial appointees and military advisors, and at the end of 1979 several thousands of troops were sent as direct military 'assistance'. A new more pro-Soviet President, Babrak Karmal, was installed after the incumbent was finally killed (Hassan 1995).

The Soviet-backed regime sought to align socialism with Islamic social justice, using Russian financial aid to extend social services. However, the presence of over 120,000 Russian troops in Afghanistan inflamed nationalistic sentiments, and forceful resistance was unified into the 
Afghan 'Mujahideen', backed by the Pakistan state. The ensuing nationalist war displaced more than six million Afghans into surrounding countries. From 1985, under Mikhail Gorbachev, the Soviets encouraged power sharing with the 'Mujahideen' and in 1986 installed Muhammad Najibullah as PDPA President to negotiate a truce and put in place a new constitution. This was to allow the Soviet forces to be withdrawn, which they were in 1989 (Kaplan 2001). The constitution was revised in 1990 to remove references to communism, re-founding Afghanistan as a 'unitary and Islamic state', and Najibullah remained in power until 1992 when Russian aid ceased. His execution in 1996, after four years of civil war, announced the arrival of the Taliban regime. In his in-depth study of the Russian occupation and the civil war period, Sharma suggests a transition from ideological politics to identity politics, directly linked to militarisation (Sharma 2017). In this he highlights how ethno-regional identity was mobilised against the Russian invasion and then later used a resource against political Islam, in part through external proxy-formation. This legacy directly shaped elite-formation post-2001.

The ethno-political history of Afghanistan, to the rise of the Taliban in 1996, demonstrates the country's political lineage as a crossroads or meeting point between global ideologies of nationalism, liberalism and communism, in a local context embedded in Islamic traditions and regionalist or tribal political formations. The polity has oscillated across combinations of nationalism and Islam, with institutions variously centred on monarchical, democratic and theocratic power. The history sheds light on the current constitutional arrangements and institutional practice, which, initially centred on post-conflict clientelism and related ethnocratic institutional structures.

\section{The meaning of ethnicity in Afghanistan}

The concept of ethnicity in Dari, the dominant Afghan language, is most closely expressed in the term 'Qawm', which refers to a group of people who have a common ancestry, common language and culture, and a shared history and heritage. However, in Afghanistan, more markedly than in many other places, the meaning of ethnicity is blurred and shaped by other forms of identification. As Schetter observes, through the nineteenth century, 'identities [were] derived from tribal origin, religious or sectarian belonging, social status and profession', noting these 'societal boundaries and group formation altered in place and time' (Schetter 2005a, p. 5). Despite strong cross-border ethnic links, for instance for Pashtuns into 
Pakistan, for Tajiks in Tajikistan, and Uzbeks with Uzbekistan, there has been no serious movement for secession or irredentism in Afghanistan (unlike in other post-colonial contexts). Regional powers have intervened to support ethnicised proxies, Pakistan for Pashtuns, Iran for Hazarras and Tajiks, but this has not translated into an irredentist political project. Afghan nationalism, in this respect, is dominant.

Despite the recent decades of military conflict, many people remain unaware of their presumed ethnic background and simply call themselves Muslims without thinking about their ethnicity (Schetter 2005a, p. 6). Pashtuns are often said to be the biggest ethnic group in Afghanistan, at approximately forty to sixty per cent of the population. Yet Pashtuns are highly diverse, regionally, politically and culturally. While the Pashtun language, Pashto, is dominant, many Pashtuns speak Dari, which is the language of the Tajiks, who are said to be the second largest group in the country. Both languages are officially recognised, but there are more people speaking Dari on a daily basis than Pashto - and many Pashtuns cannot speak Pashto. The culture of ethnic groups is likewise highly diverse and syncretic. There has been much internal migration, inter-mixing and cultural exchange. There are elements of Pashtun culture, for instance, which have been adopted by other groups in Afghanistan. For example the Pashtuns' dance, Attan, has become a national dance for all ethnic groups in Afghanistan and the Pashtuns have equally adopted elements of other cultures in the arts, food and language.

Certainly, since World War II the country has been more influenced by European assumptions about political identity, but these were often constructed. There are claims, for instance, that some of the names for Afghanistan's ethnic groups were invented by European observers. Schetter, for example, notes how 'anthropologists such as Schurmann invented ethnic groups such as the Pashai, Tajiks, Mountain-Tajiks or Farsiwans', creating the term Tajik, 'which was usually used in social interactions only in a negative sense for somebody who did not belong to any group but merely shared the belief in a common tradition, implied an anti-ethnic notion in general...' (Schetter 2005a, p. 5). Reflecting this, regional and tribal affiliation is often a stronger market of identity: in Afghanistan people often identify themselves by where they were born, a locality that they identify with, such as Charikarie, Kabuli, their tribes and clans such as Barakzaie, Alokzaie, or by their occupations. Ethnicity is still not a primary category of everyday identity. If people do make reference to their ethnicity, it is often for the purpose of formally defining ancestry with the authorities. 
Despite decades of conflict, it is significant that Afghanistan has never 'suffered from a secessionist movement, even though there have been serious conflicts between groups' (Adeney 2008, p. 539). The civil conflicts have hollowed-out national elites: the Soviet invasion in 1979, with the subsequent civil war and eventual installation of the Taliban in 1996, saw an exodus especially of urban middle classes into neighbouring refugee camps in Iran and Pakistan; 4 million people returned after the 2001 invasion, but, as noted, under occupation the country's elites failed to generate economic autonomy and instead became increasingly orientated to international aid flows. As the security situation deteriorated from 2005, the exodus began again, increasing numbers to 3 million in Pakistan alone (which announced mass forced repatriation in 2016; Admadi and Lakhani 2016).

With ethnicity mobilised at the elite level, kinship is more central in everyday life. Afghanistan has been in a state of war and conflict for decades, and during this time it is not ethnicity that has sustained communities. Rather, it is been much more everyday structures of kinship and clientelism that have enabled survival: 'informal social security systems have been of critical importance in Afghanistan' (Schütte 2009, p. 479). Family and kinship is the major means of support in the times of crisis, and offers a foundational form of identity, linked with regional and tribal affiliations. In a country where civil society and the state are weak, kinship governs the individual's life and activities (Wimmer and Schetter 2003). In Afghanistan when people refer to their family they generally mean their extended family, often across a kin-based network with several hundred members, linked through strong social and economic bonds (Tapper 1991).

Kinship links with wider clientelist structures. These have their origins in the originally feudal system of Arbab wa Rayat, or 'client and patron'. In this system, family or tribal leaders, landholders or employers, provide protection for the individuals that depend on them. Such protection creates an obligation for the Rayat or client, who must show their absolute loyalty to the Arbab or patron, when required. There also more informal structures of community duty for the well-off. In most neighborhoods there are individuals who support their locality, as part of their religious observance. Under the name of Khairat or baraie Khada (charity in the name of God or because of God), respected and wealthy members of a locality devote an amount of their daily income to the poorer members of their neighborhood. 
With the breakdown of state authority and civil conflict since 1979 dependence on these systems of mutual obligation has spread, so that many Afghans are now somehow connected a powerful patron. Sharan argues these relations 'characterise the daily politics of contemporary Afghanistan... in which selective benefits are distributed to individuals or groups in exchange for loyalty or political support'; they then 'link factional elites and their regional-ethnic or tribal clients to the state' (Sharan 2011, p. 1119). He characterises the postinvasion political settlement as centring on the accommodation and legitimation of ethnoregional elites, producing a heightened ethnicisation of politics.

In the context of on-going military conflict, kinship, clan membership, tribal relations, religious obligation, local codes of honor and customary means of conflict resolution have become more important. As Schetter argues, 'The permanent conditions of war since 1979 did not impair the significance of family, but the increased insecurity strengthened the role of kinship and clientelism. Distrust grew to such an extent that clientelism spread to almost every sphere of the Afghan society' (Schetter 2005a, p. 10). In the cities informal sources of social obligation have been weaker, especially amongst those internally displaced by conflict, leaving 'a deep sense of insecurity for the urban poor', and approximately eighty per cent of the urban population relying on informal sources of livelihood and shelter. (Schütte 2009, p. 479).

Informal clientelism as a social practice is distinct from state corruption, which is extensive and has deeply corrosive effects (Braithwaite and Wardak 2013). Rangelov and Theros found that the 'system of governance gives rise to an acute sense of injustice among ordinary Afghans, as they witness the contrast between their own deprivation and daily struggle for survival, and the growing wealth of a privileged group of officials and power brokers' (Rangelov and Theros 2012, p. 236). State security is contracted to foreign security companies, which employ local sub-contractors, often former Mujahidin commanders and warlords, who have the power to enforce bribery. Funds are routinely exported: in 2011 US\$4.6 billion of declared funds left Afghanistan via Kabul airport, an amount equivalent to the country's entire state budget for that year (Rangelov and Theros 2012; see also Shahrani 2015).

Another consequence of the decades-long internal conflict is the emergence of strong informal justice systems. This 'legal pluralism’ reflects the lack of trust in an often corrupted 
state, or simply the absence state of state authority (Wimpelmann 2013). The rule of law established post-2001 has been set up in combination with tribal and Islamic sources of legal authority. More or less institutionalised, informal justice varies across regions and population groups. Afghan Pashtuns, for instance, live under three regimes - Afghan law, the tribal rule of Pashtun Wali, and the Islamic Sharia - with community judges arguing all three are compatible.

Often considered the ideal type of informal justice is the image of the jirga (Barth 1959; Carter and Connor 1989, 7; Rzehak 2011). Jirga is a Pashto word for a purpose-specific gathering of entrusted men tasked to make a decision or resolve a dispute. Through discussion, the representatives agree upon a settlement to restore honour, to which the parties are expected to adhere; women rarely participate and may themselves become part of the compensation package, a practice called baad (Boesen 1983). Since 2001 various efforts at reforming and formalizing these 'hybrid' arrangements have not been successful, forcing a continued pragmatic use of informal structures in the context of the on-going Taliban insurgency (Wimpelmann 2013).

\section{From Warlordism to Ethnocracy}

When global and regional powers intervene in Afghanistan they have invariably assumed the existence of ethnic division. One example is Tomsen's account of US diplomacy in the region, which highlights great power manipulations in the country: in doing so it exposes assumptions about ethnic rivalry, especially in the immediate post-Communist civil war (Tomsen 2011). Intervention, whether to favour one ethnic group over another, or to 'manage' inter-ethnic relations, preempts the possibility of other foundations for political solidarity, be they tribal, religious, regional or national. Often external observers assume that ethnic groups have a clear and distinct identity, and read local conflicts as ethnic disputes. One journalist recently replicated the recurrent claim about Afghans, that 'historically when they haven't been united fighting outsiders, they've been fighting each other' (Campbell 2013).

Certainly, political institutions are dominated by Pashtuns. Under the British Empire, Pashtun elites were favoured as a bulwark against Russian influence: 'Pashtuns were privileged in all areas and dominated the military; Tajiks were left with the economic sector and the educational institutions, whereas the Hazaras were marginalised in general' (Schetter 2005a, p. 7). Political power since the eighteenth century has almost exclusively been held by 
Pashtuns, and the creation of a Pashtun state extending into Pakistan has been pursued by the leadership, for instance under Prime Minister Sardar Muhammad Daoud Khan, 1953-1963. Reflecting these legacies, political conflict is often attributed to Pashtun domination, and assumes primordial ethnic identification. Such accounts then drive policy, especially in relation to state-building efforts by the Soviet Union after 1979, and later under the US from 2001.

Consecutive Soviet-aligned governments in Kabul had warned people of foreigners' plans to divide the country on ethnic lines. There was some degree of truth in this as both Iran and Pakistan had an interest in ethnicising the war, and funded ethnic proxies to achieve this (Pstrusinska 1990). Iran supported mainly Hazaras, based on their religious connection, and the Tajiks because of their language and cultural connection; Pakistan supported Pashtun groups because of their shared Pashtun heritage. Warlords themselves, seeing no other basis for their legitimacy, would assert ethnic leadership to convince foreign donors they had a broad constituency within Afghanistan. The Soviet Union labeled the rebel groups as the agents of foreign countries aiming to divide Afghanistan on ethnic lines. Once again, there was some truth in this as many of the so-called Mujahedin were in close association with foreign funders. With the Soviet invasion, fear of ethnic conflict was commonplace: the regime attempted to de-ethnicise the state, but Pashtun elites persisted (Roy 1986). The collapse of the PDPA regime from 1992 led to civil war, but it was not a war between ethnic groups, rather between rival warlords and their respective militias (Giustozzi 2012).

During the civil war thousands of people lost their lives but ethnic groups kept relative peace with each other. The main ethnic victim of the civil war was the Hazara Shia minority, although anti-Hazara attacks also reflected religious sectarianism. Post-1996 the Taliban regime was Pashtun-led, and systematically repressed Shia Muslims and in particular the Hazaras in a number of cities in Afghanistan, on a sectarian basis. With the collapse of the Taliban government and the U.S war in Afghanistan in October 2001, there was once again speculation over the possibility of ethnic war. Yet since 2001 there has been relatively little in the way of ethnic conflict, especially given the scale of dislocation and conflict in the country. Ethnic displacement that had occurred in northern Afghanistan under the Taliban, in favour of Pashtuns, was reversed, with the expulsion of an estimated 20,000 Pashtuns from 2001 (Schetter 2005b). Another exception concerns a number of clashes between the nomadic Pashtun tribes and Hazaras around Bamyan, reflecting intensified competition between the 
groups for access to water and land, and a range of sectarian anti-Hazara attacks, including by Taliban militants on Hazara refugees in Pakistan.

The relative absence of ethnic conflict contrasts with the ethnicisation of state power. Following the US invasion, the new architects of the state sought to unify the polity and publicly downplayed ethnic division. The international community, the United Nations and supporting NGOs sought to ensure that all ethnic groups would have a role in the political and social life of the country (Wafayezade 2015, p. 15). In practice, though, state power was used to translate the power of contending militias into modes of ethnic leverage: power blocs were de-militarised, but also ethnicised. As Schetter argues, 'every Afghan was assigned to a certain ethnic affiliation: the 'Uzbek Dostum', the 'Pashtun Karzai', the 'Tajik Rabbani’ or the ‘Pashtun Zahir Shah” (Schetter 2005a, p. 10).

The UNSC Resolution 1378, adopted on 14 November 2001, had defined the framework for the post-Taliban administration, giving 'strong support' for a government that was 'broadbased, multi-ethnic and fully representative of all the Afghan people’ (UN 2001). Afghan allies of the US met at the International Conference on Afghanistan in Bonn on 5 December 2001, selecting Hamid Karzai to head the Afghan Interim Authority. The conference drew up an 'Agreement on Provisional Arrangements' which stated the interim administration had to have 'due regard to the ethnic, geographic and religious composition of Afghanistan'. Reflecting this, Karzai’s cabinet was informally a form of power-sharing, composed of 11 Pashtuns, 8 Tajiks, 5 Hazaras, 3 Uzbeks, and 2 members of other ethnic groups. Once installed in government as legitimate rulers, these ethno-military leaders then positioned themselves as ethnic representatives with a call on government posts (Mukhopadhyay 2014).

As outlined by Ali, the breakdown was follows: 'Ahmad Shah Massoud's and Burhanuddin Rabbani’s Northern Alliance became today's Jamiat-e- Islami, a primarily Tajik organisation. Uzbeks organised under Rashid Dostum’s Junbesh-e-Milli. Abdul Ali Mazari’s followers were now under the Hazara Hezb-e-Wahdat. And Pashtuns followed Gulbuddin Hekmatyar's Hezb-e-Islami... The Mujahidin, the resistance who fought against the communist government, was fractioned into groups aligned to ethnicity as well. For instance, mainly Tajiks followed Ahmad Shah Massoud, Hazaras were led by Abdul Ali Mazari, Uzbeks and Turkmens were behind Abdul Rashid Dostum, and Pashtuns were with Gulbuddin Hekmatyar' (Ali 2015, p. 10). As discussed below, there was no necessary public consensus behind these 
political blocs. Many Afghans actively oppose the leadership of these organisations. For example in 2003 Hezb-i-Islami was banned as a terrorist organisation by the UN, and Gulbuddin Hekmatyar, dubbed the 'butcher of Kabul' for his actions during the civil war, was barred from entry into Afghanisatan. His accord with the Afghan Government in 2016 has led to his attempted rehabilitation, though there is little evidence of public support amongst Pashtuns or non- Pashtuns (Rasmussen 2016).

\section{Ethnicity and the constitution}

The 2001 Bonn meeting that defined the framework for the post-invasion polity was heavily influenced by would-be ethnic leaders who (ironically) stressed the need to prevent ethnic conflict in the country. A prominent role in all peace negotiations was granted to these leaders, who then built an ethnic oligarchy within the structure of the state, sharing government positions between them while selling other lucrative positions within government departments to clients. This informal ethnic power-sharing structure is entrenched in state authority and is viewed with disdain by the wider public, which is generally excluded from its material benefits. This informal accommodation was a legacy of alliance-building under the US occupation, and contrasted with the formal constitutional arrangement post 2004.

The formal constitution was promulgated at a national deliberative conference, a Loya Jurga, held in Afghanistan in late 2003, and explicitly sought to institutionalise nationally-shared foundations for solidarity, beyond ethnic loyalty. In the first instance the constitution was grounded in religious solidarity, as the key foundation for political solidarity. It centralised power in an 'Islamic Republic, independent, unitary and indivisible state' (A.1), and defined a civic Islamic political culture, embedded in non-authoritarian models of Islam, allowing for religious freedom for other religions as well as across Islamic traditions, Shia, Sunni, Sufi. The constitution expressed a mode of inclusive political Islam in contrast with doctrinaire political Islam, in non-civic mode, where one interpretation of religious culture is asserted above others.

The constitution grounds its legal authority in Islam - it is only sovereign insofar as it is compatible with Islam. It was declared in the year 1382 on the Islamic Calendar and names Afghanistan as an 'Islamic Republic', requiring all law to conform to Islamic 'tenets and provisions'. The constitution asserts a version of Sharia law (religious law) that is compatible 
with human rights norms: provisions for the Supreme Court state that ordinarily it acts in 'pursuance of Hanafi jurisprudence, and, within the limits set by this Constitution' (Article 130) Hanafi is a School of Sunni law practiced in much of Central Asia where law is interpreted by both secular as well as religious authorities (Warren 2013). Reflecting this, the six members of the Supreme Court are appointed by elected politicians (named by the President, endorsed by Parliament), not by the religious orders.

Legal pluralism is accommodated, with the courts required to 'apply Shia jurisprudence in cases involving personal matters of followers of the Shia sect in accordance with the provisions of the law' (Article131). The framework for education exemplifies the model, in requiring a 'unified educational curricula based on the tenets of the sacred religion of Islam', along with 'curricula for schools on the basis of existing Islamic sects in Afghanistan' (Article 45). Freedom of religion is asserted within this framework, with Article 2 stating the 'followers of other faiths shall be free within the bounds of law in the exercise and performance of their religious rituals': with the 'bounds of the law' defined by Islam, religious freedom rests on respect for Islam. As such, political parties may only be established that do not ‘contravene the Holy religion of Islam’ (Article 35).

There is support for ethnic diversity, but tribalism and sectarianism is outlawed. While centralizing power, the 2004 Constitution recognised Afghanistan as a multi-ethnic country (Article 4). At the same time it explicitly forbids tribalism and sectarianism, stating the 'formation and operation of a party on the basis of tribalism, parochialism, language, as well as religious sectarianism shall not be permitted' (Article 35). Ministers were not to 'use their positions for linguistic, sectarian, tribal, religious or partisan purposes' (A80). With the state defined as impartial, the Constitution recognises ethnic identities, at Article 4 stating 'The nation of Afghanistan shall be comprised of Pashtun, Tajik, Hazara, Uzbek, Turkman, Baluch, Pachaie, Nuristani, Aymaq, Arab, Qirghiz, Qizilbash, Gujur, Brahwui and other tribes’. Article 6 then recognises the equal status of 'all ethnic groups and tribes'. This is reflected in language policy which institutionalises Pashto and Dari as first and second languages and any local language as third language (Article 16). The national anthem 'shall be in Pashto with the mention of "God is Great" as well as the names of the major ethnic groups of Afghanistan (Article 20). This recognition of local languages and tribal affiliations was, interestingly, one of the most contentious issues at the constitutional Loya Jirga, precipitating a walk-out by forty per cent of the delegates (Adeney 2008). 
Despite recognition of ethnic diversity there is no entrenched requirement for regional autonomy. A structure of provincial district and municipal councils is established, only with devolution of power as required (Article 137). Since 2004 provincial councils have been constituted and have sought increased powers and resources, though they remain relatively weak, and exist at the behest of the central state (Adeney 2008). They may, though, develop to displace centre-peripheral tensions from ethnicised competition for central resources into regionally-grounded aspirations and priorities. These local versions of the state offer the possibility of cultural provincialism, local democracy and hence legitimation, in the exercise of devolved local powers within a unitary state. In practice, though, and reflecting the military occupation, effective power has remained centralised in the Presidency.

Beyond religion and ethno-regional identification, the constitution also vests its authority in national political solidarity. Here the foundation for solidarity is the state itself, legitimised as an expression of the Afghan nation. Legitimacy may be claimed in terms of a value commitment, vested in human rights norms and national citizenship, and in terms of representation as expressed in elected national assemblies and the elected presidency. In terms of representation the 2004 constitution vests considerable power in the directly-elected President, who selects two Vice-Presidents, appoints Ministers, defines policy and appoints provincial Governors. It also establishes a directly-elected lower house 'of the people'. The parliamentary electoral system is majoritarian, with more than one candidate per constituency, elected under the Single Non-Transferable Vote system. In addition, an upper house 'of elders' is constituted from provincial and district councils, with a third of its membership appointed by the presidency. The lower house holds the legislative power; the upper house takes a more advisory role. Judicial authority is vested in an independent supreme court, which has the responsibility to enforce constitutional protections for the citizenry. The Court is to entrench human rights, non-discrimination and civil and political freedoms, qualified by undefined 'duties', and by a broader 'public interest' (Aricles 22, 23 and 24).

National identification is bolstered by a development mandate, with some guarantee of social security. At Article 6 the state is committed 'to create a prosperous and progressive society based on social justice, preservation of human dignity, protection of human rights, realisation of democracy, attainment of national unity as well as equality between all peoples and tribes and balance development of all areas of the country'. Health and education is a special focus 
with a commitment to 'free preventative healthcare and treatment of diseases' (Article 52) and for the provision of 'educational institutes free of charge by the state' (Article 43). Beyond this there is some declaratory commitment to help develop industries and agriculture (Article 17).

Set against this, some key clauses seem more directed at the interests of the occupiers than at the impoverished population. Under Article 10 the constitution requires the state to 'encourage, protect as well as ensure the safety of capital investment and private enterprises in accordance with the provisions of the law and market economy'. This neoliberal constraint on policy is bolstered by Article 11 which imposes a requirement that the central bank be independent and Article 40 which protects property from confiscation. Under Article 41 foreign ownership of immovable property is not permitted, but leasing 'for the purpose of capital investment' is. And perhaps most important, security crises can trump the constitution, with the President, as Head of State, explicitly vested with a specially-defined power to declare a 'state of emergency' where 'protection of independence and national life become impossible through the channels specified in this Constitution’ (A143).

Overall, the 2004 Constitution clearly seeks to define and entrench cross-national solidarities, whether Islamic or nationalist, recognizing local, tribal and ethnic identification within the framework of the state. Ethnicity is subsumed into the national structure, and outlawed as a basis for political mobilisation. On this basis the country has so far embarked on three electoral cycles, with elections in 2004, 2009 and 2014. The outcomes of these elections in terms of de-ethnicisation are hotly debated.

\section{Democracy and cross-ethnic de/alignment}

The role of the central state mapped out in the 2004 Constitution is one of managing and correlating ethnic identifications. As noted, in the context of the Taliban insurgency pragmatic alliance-building led to informal power-sharing structures for rule. As with powersharing arrangements more generally, these informal arrangements have had the potential to ethnicise the state as an ethnocracy, institutionalising what may be more fluid identifications (See Lijphart 1977). As noted, the 2004 Constitution is explicitly aimed at overcoming ethnic division and preventing ethnocracy, and articulates an amalgam of Islamic and national solidarity to achieve this. Arguably, the implementation of the constitution could open up 
new possibilities for cross-ethnic bargaining and allow the creation of new forms of nonethnicised national-level political antagonism. Electoral outcomes, and the extent to which Afghan voters have become more or less aligned into rivalrous ethnic blocs, are a crucial measure of this.

A strong narrative of de-ethnicisation, as reflected in voting patterns, is widely claimed. The majoritarian electoral system is said to encourage cross-ethnic alliance-building in the presidential election given that the dominant Pashtun group only claims at most forty percent of the national electorate. Nonetheless, ethnicisation in the 2004 presidential election was extensive. This serves as a baseline, directly reflecting the initial ethnicisation of formal interparty politics. In 2004 the overwhelming majority of voters cast their vote for a co-ethnic candidate: ninety-five percent of Pashtuns voted for Karzai, ninety percent of Uzbecks for Dostum, eighty percent Hazaras for Mohaqiq; there was a similar ethnicisation in the 2005 parliamentary election. Giustozzi argues that the main drivers for this were the absence of ideological disputation in the country's first election since the Taliban regime, along with weak class formation, low state capacity and the impact of external influences (Giustozzi 2015). The relative lack of political antagonism in the context of the Taliban insurgency may have been a contributing factor.

The 2009 election was seriously corrupted by the incumbent president, with about a fifth of the votes invalidated. Mobasher's forensic analysis of cross-ethnic voting, between 2004 and 2009, province-by-province, reveals a complex structure of inter-ethnic bargaining, initiated by President Karzai and built into the structure of the state (Mobasher 2016). Against this, some observers claimed strong signs of ethnic de-alignment between the 2004 and 2009 Presidential elections. Dubow for instance analysed the ethnic and spatial distribution of votes from 2004 to 2009, finding a significant shift away from ethnic blocs; the 2009 parliamentary election even superseded sectarian conflict, for instance with a Shiite Hazara candidate receiving the majority of his votes from Sunnis and non-Hazaras (Dubrow 2009).

The 2014 presidential election was also extensively corrupted, requiring a full recount. Yet it is also seen as signaling a new departure, as Mobasher notes, 'the scale of cross-ethnic voting in the Afghan election of 2014 was extraordinary’ (Mobasher 2016, p. 369). In this context inter-ethnic bargains appeared to unravel in a wider context of political contention. Dealignment was encouraged by a change in electoral rules in 2013 that required presidential 
candidates to gather 100,000 signatures or two percent of those enrolled, across twenty provinces. Partly reflecting this, the only candidates to nominate were from the larger Pashtun and Tajik ethnic groups. In the election most Hazaras voted for the Tajik candidate, and most Uzbeks for the Pashtun candidate. In the Presidential poll the Pashtun vote split between a Tajik candidate, Dr Abdullah (formerly of Northern Alliance militia, also favoured by Tajiks and Hazaras), and a Pashtun candidate, Dr Ghani (who also attracted Uzbek support). In the context of a corrupted Electoral Commission the formal vote was never released and the two candidates resolved to exercise power in tandem, with Ghani as President and Abdullah in a (non-constitutional) ‘Chief Executive’ role.

Interpreting the outcome is itself part of the political dynamic: one person's ethnic bargaining is another person's cross-ethnic collaboration. Mobasher for instance emphasises inter-ethnic bargaining rather than cross-ethnic de-alignment, stressing the 'persistence of ethnic voting and mobilization' (Mobasher 2016, p. 412). In contrast, Sharma points to the 2014 election as demonstrating the 'failure of neat ethnic homogeneity to stabilise, in spite of long years of armed bloody mobilization along ethno-political lines’ (Sharma 2017). The disagreement turns on the interpretation of inter-ethnic voting patterns and associated political accommodations at the elite level: at one level they entrench ethnic division; at another level they introduce new lines of non-ethnic antagonism.

In this respect Sharma argues that 'political alliances... have not followed the neat simplistic ethnic logic of the kind often projected as the eternal fact of Afghan social political life' (Sharma 2017, p. 151). Rather, they have a life of their own, shaped by a wide range of contingent, non-ethnicised matters. For Sharma, ethnicity is seen as a changing resource, with post-2001 demands for ethnic parity positioned as a political manoeuvre. Certainly ethnicity has become more salient in elite bargaining, but at the same time Islam and the idea of the nation have strengthened as identifiers. The result is a potentially complementary set of national, ethno-regional and religious solidarities, producing an amalgam, a co-national ethno-religious identification.

\section{Conclusions}

In 2010 the US Defence Secretary and the US Brigadier General in Afghanistan debated their reliance on what they termed 'thugocracy' in Afghanistan, as a necessary evil in their 
struggle against Taliban-style ‘theocracy’ (quoted in Shahrani 2015, p. 296). One question that arises in the context of the 2014 election and the 2015 US military withdrawal is whether that US-sponsored 'thugocracy' is now in transition to 'ethnocracy' or 'democracy'. The signals are mixed, but there is certainly evidence of a changing political landscape. One key factor, as argued here, is the relative weakness of ethnic identification in Afghan society, both historically and in the current period. Non-ethnic and localised affiliations appear to have gained greater social importance in the context of on-going civil conflict. In contrast, ethnic identification is more confined to elite-level bargaining, where it serves as a proxy for military rivalry. At the same time, the constitution, and growing autonomy following the US withdrawal, appears in some respects to have facilitated cross-ethnic bargaining, disrupting bloc formation. As inter-elite rivalry gives way to strategic alliance-building we can expect stronger cross-ethnic ideological engagement, especially on national development concerns relating to gender and poverty. From this perspective Afghan politics may be moving into a post-ethnocratic phase, and towards the form of Islamic democracy envisaged under the constitution.

Afghanistan's long history of inter-ethnic relations, overlaid with religious and national solidarities, and hingeing on local-level loyalties and obligations, has not readily embraced ethnicised politics. Despite the ethnicisation of militias and elites, and a history riven with social dislocation and conflict, the country has not, as a rule, experienced ethnic conflict on the scale common in parallel contexts. The long period of externally-funded warlordism, civil war, and then occupation, instituted a model of inter-ethnic and ethnocratic rule, yet this appears to have been only weakly entrenched in Afghan society. The logic of US occupation, of sustaining a military alliance against an increasingly nationalist Taliban insurgency, underpinned the continued ethnicisation of politics. As argued here, there is some evidence that this model of political rule may be receding with the end of the occupation and the return of political independence. This suggests a strong relationship between occupation and ethnocracy, potentially relevant to other contexts.

Certainly, wider research points to the corrupting effect of military occupation, especially in undermining prospects for strengthened identification with national-level elites (Braithwaite and Wardak 2013). Post-occupation there are signs of a revival of national-level political culture. Against this, there are inherent dangers of ethnic hegemony in the centralised winnertakes-all model, as reflected in the electoral system and the presidential structure. In this 
context Adeney argues there is a risk of ethno-regionalist alienation, and argues for much stronger guarantees of multi-ethnic power-sharing (Adeney 2008). This approach assumes (and we would argue, imputes) abiding ethnic identification, and may have the effect of institutionalizing inter-ethnic rivalry. The informal elite model of ethnic-military accommodation established in 2001 may be now be in the process of being superseded by new forms of political bargaining and national level contention. In this context new political blocs may emerge, grounded in the deep structural stratification of Afghan society, claiming the capacity to displace the militarised ethnocracy of the occupation period. As the Afghan people gain greater control of their political destiny, after decades of occupation and militarisation, there appears to be a new dynamism.

\section{Acknowledgement}

We are grateful to the anonymous reviewers whose advice helped us to strengthen this paper.

\section{References}

Adeney, K. 2008, 'Constitutional design and the political salience of 'community' identity in Afghanistan: Prospects for the emergence of ethnic conflicts in the post-Taliban era', Asian Survey, no. 484, pp. 535-557. doi: https://doi.org/10.1525/as.2008.48.4.535

Admadi, B. and Lakhani, S. 2016, 'The forced return of Afghan refugees and implications for stability’, Peace Brief, no. 199, United States Institute for Peace, Washington, 13 January. Available at: https://www.usip.org/publications/2016/01/forced-return-afghanrefugees-and-implications-stability

Ali, F. 2015, Afghanistan: the rise of ethnic consciousness through history; a comprehensive overview of the origin of the Afghan conflict, Working paper, Leibnitz Institute. Available at: http://www.ssoar.info/ssoar/bitstream/handle/document/43832/ssoar2015-ali-Afghanistan the rise_of_ethnic.pdf?sequence $=1$

Axworthy, M. 2009, The Sword of Persia: Nader Shah, from Tribal Warrior, I. B. Tauris \& Company, London.

Barfield, T. 2010, Afghanistan: A Cultural and Political History, Princeton University Press, New Jersey. doi: https://doi.org/10.2307/j.ctt7sqkc, https://doi.org/10.1515/9781400834532 and https://doi.org/10.1353/book.36278

Biswas, A. 2013, The Durand Line: History, Legality \& Future, Occasional Paper, Vivekananda International Foundation, New Delhi.

Braithwaite, R. and Wardak, A. 2013, 'Crime and war in Afghanistan', British Journal of Criminology, no. 522, pp. 179-196. doi: https://doi.org/10.1093/bjc/azs065

Campbell, E. 2013, 'Foreign Correspondent', Australian Broadcasting Corporation, 17 September. Source: http://www.abc.net.au/foreign/content/2013/s3850711.htm, Accessed 1 December 2016.

Defence Committee for Malalai Joya 2016, 'Speech to the 2003 Loya Jirga’. Source: http://www.malalaijoya.com/dcmj/ Accessed 1 December 2016.

Dimitrakis, P. 2013, Secret War in Afghanistan, I. B. Tauris \& Company, London. 
Dubow, B. 2009, Ethnicity, Space, and Politics in Afghanistan, Working Paper, University of Pennsylvania, Urban Studies Program.

Fair, C. and Gregory, S. eds, 2013, Pakistan in National and Regional Change: State and Society in Flux, Routledge, London.

Fremont-Barnes, G. 2014, The Anglo Afghan Wars 1839-1919, Osprey Publishing, Oxford.

Gibbs, D. 2000, 'Afghanistan: The Soviet invasion in retrospect', International Politics, vol. 37, pp. 233-246. doi: https://doi.org/10.1023/A:1009810614470 and https://doi.org/10.1023/A:1009817421313

Giustozzi, A. 2012, Empires of Mud: War and Warlordism in Afghanistan, Oxford University Press, Oxford.

Giustozzi, A. 2015, 'Processes of ethnicization in today's Afghanistan', in CentlivresDemont, M. ed., Afghanistan: identity, society and politics since 1980, Tauris, London, pp. 211-14.

Goodman. J. 2013, 'Humanitarian collective security: restoring order?' Global Networks, no. 133, pp. 345-62. doi: https://doi.org/10.1111/glob.12026

Hiro, D. 1995, Between Marx and Muhammad: Changing Face of Central Asia, HarperCollins, New York.

Holt, F. 2012, Lost World of the Golden King: In search of Ancient Afghanistan, University of California Press, Berkeley.

Kamel, K. 2015, 'Understanding Taliban resurgence: Ethno-symbolism and revolutionary mobilization', Studies in Ethnicity and Nationalism, vol. 15, no.1, pp. 66-82. doi: https://doi.org/10.1111/sena.12128

Kaplan, R. 2001, Soldiers of God: With Islamic Warriors in Afghanistan and Pakistan, Vintage, New York.

Khan, R. M. 2011, Afghanistan and Pakistan: Conflict, Extremism, and Resistance to Modernity, John Hopkins University Press, Baltimore.

Krivosheev, G.F. 1997, Soviet Casualties and Combat Losses in the Twentieth Century, Greenhill Books, London.

Lijphart, A, 1977, Democracy in Plural Societies, Yale University Press, New Haven

Maley, W. 2016, 'Afghanistan on a knife-edge', Global Affairs, vol. 2, no.1, pp. 57-68. doi: https://doi.org/10.1080/23340460.2016.1159865

Mobasher, M. 2016, 'Understanding ethnic-electoral dynamics: how ethnic politics affect electoral laws and election outcomes in Afghanistan’, Gonzaga Law Review, vol. 51, no. 2, pp. 356-415.

Mukhopadhyay, D. 2014, Warlords, Strongman Governors, and the State in Afghanistan, Cambridge University Press, Cambridge.

Pstrusinska, G. 1990, ‘Afghanistan 1989 in Sociolingustic Perspective’, Central Asian Survey, Incidental Paper Series, no. 7.

Rangelov, I. and Theros, M. 2012, 'Abuse of power and conflict persistence in Afghanistan', Journal of Conflict, Security and Development, vol. 12, no.3, pp. 227-248. doi: https://doi.org/10.1080/14678802.2012.703533

Rasmussen, S. 2016, 'Butcher of Kabul' pardoned in Afghan peace deal', The Guardian, 22 September.

Roy, O. 1986, Islam and Resistance in Afghanistan, Cambridge University Press, Cambridge. Rubin, B. 1995, The Fragmentation of Afghanistan, Yale University Press, New Haven, CT.

Schetter, C. 2005a, 'Ethnicity and the Political Reconstruction in Afghanistan', ZEF Working Paper Series, No. 3, Centre for Development Studies (ZEF), University of Bonn, Bonn.

Schetter, C. 2005b, 'Ethnoscapes, national territorialisation, and the Afghan War', Geopolitics, vol. 10, no.1, pp. 50-75. doi: https://doi.org/10.1080/14650040590907712 
Schütte, S. 2009, 'Informal insecurity in urban Afghanistan', Iranian Studies, vol. 42, no. 3, pp. 465-91. doi: https://doi.org/10.1080/00210860902907404

Shahrani, N. 2015, 'The impact of the 2014 U.S.-NATO withdrawal on the internal politics of Afghanistan: Karzai-style Thugocracy or Taliban Theocracy?’ Asian Survey, vol. 55, no.2, pp. 273-98. doi: https://doi.org/10.1525/as.2015.55.2.273

Sharan, T. 2011, 'The dynamics of elite networks and patron-client relations in Afghanistan', Europe-Asia Studies, vol. 63, no. 6, pp. 1109-1127. doi: https://doi.org/10.1080/09668136.2011.585764

Sharma, R. 2017, Nation, Ethnicity and the Conflict in Afghanistan: Political Islam and the Rise of Ethno-politics 1992-1996, Routledge, London.

Tapper, N. 1991, Bartered Brides. Politics, Gender and Marriage in an Afghan Tribal Society, Cambridge University Press, Cambridge. doi: https://doi.org/10.1017/CBO9780511521157

Tomsen, P. 2011, The Wars of Afghanistan: Messianic Terrorism, Tribal Conflicts, and the Failures of Great Powers, Public Affairs, New York.

Tripodi, C. 2010, 'Grand Strategy and the Graveyard of Assumptions: Britain and Afghanistan', 1839-1919, Journal of Strategic Studies, vol. 33, no. 5, pp. 701-725. doi: https://doi.org/10.1080/01402390.2010.498252

United Nations 2001, 'Security Council endorses Afghanistan agreement on interim arrangements signed yesterday in Bonn', Resolution 1383 2001, 6 December.

Wafayezade, M. Q. 2015, Ethnic Politics and Youth Political Participation in Afghanistan, Heinrich Böll Stiftung and Afghanistan Peace Initiatives, Berlin, September 2015.

Warren, V. 2013, 'The Hanafi School', Oxford Bibliographies Online, 28 May, Source: http://www.oxfordbibliographies.com Accessed 1 December 2016.

Williamson, M. 2001, Terrorism, War and International Law: The Legality of the Use of Force against Afghanistan in 2001, Ashgate, Aldershot.

Wimmer, A. and Schetter, C. 2003, 'Putting state-formation first: some recommendations for reconstruction and peace-making in Afghanistan', Journal of International Development, vol. 15, no. 5, pp 525-539. doi: https://doi.org/10.1002/jid.1002

Wimpelmann, T. 2013, Nexuses of knowledge and power in Afghanistan: the rise and fall of the informal justice assemblage, Central Asian Survey, vol. 32, no. 3, pp. 406-422. doi: https://doi.org/10.1080/02634937.2013.835200

\section{Statement of Conflict of Interest}

James Goodman is an editor of this special issue. He was not involved in the review of this submission which was conducted at arms' length.

\section{Funding}

This paper was written without funding. 